ИНДИВИДУАЛНО ПЛАНИРАНОМ ИСХРАНОМ ДО РЕМИСИЈЕ КОД АДОЛЕСЦЕНТА СА DIAВЕТЕS МЕLLITUS ТИПОМ 1 И ОЧУВАНОМ ПАНКРЕАСНОМ РЕЗЕРВОМ - ПРИКАЗ СЛУЧАЈА

Весна Динов ${ }^{1}$, Анита Накић$^{2}$, Наташа Михајловић ${ }^{3}$

\title{
THE MEDICAL NUTRITION THERAPY (INDIVIDUAL DIET MEAL PLAN) IN ACHIEVING REMISSION IN ADOLESCENT WITH DIABETES MELLITUS TYPE 1 AND PRESERVED PANCREATIC BETA CELL FUNCTION - CASE REPORT
}

Vesna Dinov, Anita Nakić, Nataša Mihajlović

\section{Сажетак}

Diabetes mellitus јехронично, прогресивно обољење са великом заступьеношћу у свим добним групама са порастом преваленције код деие и младих. Док се раније код деце јављао само дијабет тип 1, од недавно се дијагностификује и дијабетес типа 2. Иако је значајан напредак у лечену дијабетеса остварен фармакотерапијом, код великог броја оболелих контрола гликемије је и даље незадовољавајућа, а то важи и за пацијенте млађег узраста.

Циљ овог рада је да се на основу изабраног случаја утврди да ли у лечењу адолесиентног пацијента са Diabetes mellitus типом 1 и очуваном панкреасном резервом поред фармакотерапије, индивидуална планирана исхрана може утицати на постизағе ремисије, повољне гликорегулачије, спречавағе прогресије болести и развоја компликација.

Приказани адолесиент узраста 14 година маја 2007. године јавља се лекару због појачаног осећана жеђи, учесталог мокрења дању и ноћу, сушењ а устију и малаксалости. Лабораторијске анализе: глукоза укрви 28, 8 mmol/l, HbAlc 13, 7\%, гликозурија. Cохасіае вирус 5 - IgG антитела повишене вредности. Постављена дијагноза Diabetes mellitus тип 1 са очуваном панкреасном резервом. Терапија: инсулин и индивидуални

\section{Summary}

Diabetes mellitus is a chronic progressive disease and one of the commonest diseases in all age groups with increasing prevalence in children and young people. Earlier, children only suffered from Diabetes type 1, but more recently they have been diagnosed with $\mathrm{Di}$ abetes type 2. Although significant progress has been made in the treatment of diabetes thanks to pharmacotherapy, a large number of patients still have unsatisfactory glycemic control, that is especially noticeable among younger patients.

The purpose of this case report was to determine, beside pharmacotherapy, whether medical nutrition therapy in adolescent patient with Diabetes mellitus type 1 with preserved pancreatic beta cell function can affect the achievement of remission, favorable glycemic control, prevention of disease progression and development of complications.

Presented 14-year-old adolescent, in May 2007, was complaining of increased thirst, frequent urination throughout the day, even at night, dry mouth and fatigue. Laboratory analysis: blood glucose - $28.8 \mathrm{mmol} / \mathrm{l}$, HbAlc$13.7 \%$, glycosuria. A raised level of Coxsackie $B$ virus - IgG antibodies. Diabetes mellitus type 1 , with preserved pancreatic beta cell function was diagnosed. Therapy: Insulin and individual healthy eating pattern in compliance with

\footnotetext{
${ }^{1}$ Др Весна Динов, лекар на специјализацији опште медицине, Здравствени центар Врање, Служба опште медицине, Дом здравља Врање, ЈЈ Лунге 1.

2 Др Анита Накић, лекар на специјализацији опште медицине, Здравствени центар Врање, Служба опште медицине, Дом здравља Врање, ЈЈ Лунге 1.

${ }^{3}$ Др Наташа Михајловић, лекар на специјализацији опште медицине, Здравствени центар Зајечар, Служба кућне неге, Расадничка бб.
} 
планирани јеловник, усклађен са препорукама Дијабетског савеза Србије (Diabetes Association of Serbia (DAS). Планираним режимом исхране и променама у стилу живота у првом месеиу ремисије редукована је инсулинска терапија до потпуног искључења. Осии тога, уз повољнугликорегулаиију, постигнута је успешна четворогодишња ремисија, ублажени нежељени симптоми, очувана функиија панкреаса и спречен развој компликација.

Закључујемо да се код самодисциплинованог, добро едукованог пачијента, применом нутритивне терапије у лечењу дијабетеса типа 1 са очуваном панкреасном резервом, постиже смањење дозе медикаментозне терапије у корелачији са гликемијским профилима, смағује оптерећење панкреаса, ублажавају нежељени симптоми, спречава прогресија болести и развој компликација.

Кључне речи: дијабет, планирана исхрана, ремисија. recommendations of the Diabetes Association of Serbia (DAS). Thanks to diet meal plan and lifestyle changes in the first month of remission, insulin therapy was reduced to complete exclusion, with a favourable glycemic control, it was achieved 4-year remission, unwanted symptoms were eased, pancreatic beta cell function was preserved and development of complications were prevented.

In conclusion, if the patient is self-disciplined and well-educated, implementation of diet meal plan in the treatment of Diabetes type 1 with preserved pancreatic beta cell function achieves a dose reduction of drug therapy in correlation with glycemic profiles, reduces the load on the pancreas, eases unwanted symptoms, prevents disease progression and development of complications.

Keywords: Diabetes, diet meal plan, remission.

\section{УВОД}

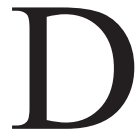
iabetes mellitus, хронично, прогресивно обољење које се карактерише хипергликемијом и другим биохемијским поремећајима, настаје због неадекватне продукције или неадекватног дејства инсулина и може се јавити у било ком узрасту након рођења. У последњих неколико деценија, преваленција дијабетеса код деце и младих је у сталном порасту. ${ }^{(1)}$ Раније се код деце и адолесцената јављао само дијабетес тип 1, а од недавно се све чешће дијагностикује и дијабетес тип 2.(2) Генетски фактори нису пресудни у патогенези ове болести у детињству. ${ }^{(3)}$

Иако је значајан напредак у лечењу дијабетеса остварен фармакотерапијом, код великог броја оболелих контрола гликемије је и даље незадовољавајућа, а то важи и за пацијенте млађег узраста. Навике у исхрани и стил живота су посебно важни код млађих пацијената, као и низ додатних фактора који су тек у разматрању. ${ }^{(4)}$ Индивидуално планирана исхрана код оболелих од дијабетеса заснива се на планираном уносу разноврсних намирница задовољавајуће енергетске вредности са адекватним садржајем микронутријената. Оваквим начином исхране може се редуковати количина потребног лека или инсулина. ${ }^{(5)}$

Циљ овог приказа случаја је утврдити да ли у лечењу адолесцентног пацијента са Diabetes mellitus типом 1 и очуваном панкреасном резервом поред фармакотерапије и индивидуална планирана исхрана може утицати на постизање ремисије, повољне гликорегулације, спречавање прогресије болести и развоја компликација.

\section{ПРИКАЗ СЛУЧАЈА}

Адолесцент узраста 14 година и 9 месеци маја 2007. године јавља се лекару због појачаног осећања жеђи, учесталог мокрења дању и ноћу, сушења устију и малаксалости. Наводи да ове тегобе има 
5 до 6 дана уназад и да је током дана до доласка на преглед попио до 5 литара течности. Негира постојање других тегоба, док родитељи наводе податак о губитку телесне тежине од неколико килограма. На пријему пацијент је хемодинамски стабилан, са високом телесном тежином за свој узраст, свестан, еупноичан, очуваног тургора коже, зажарених образа. Налаз по системима уредан. Увидом у здравствени картон види се да досад није боловао од озбиљнијих болести, сем ретких респираторних инфекција, од којих је последња регистрована пре неколико недеља.

Пацијент наводи да је досад у исхрани користио намирнице богате угљеним хидратима и мастима. Породична анамнеза на Diabetes mellitus je негативна.

Лабораторијске анализе на пријему у болницу: глукоза у крви $28,8 \mathrm{mmol} / \mathrm{l}$ референтне вредности у нормалним условима мерена наште пре оброка, она се креће у пуној крви од 3,4 до 5,5 mmol/l, a у серуму о 3,8 до 6,1 mmol/1, DCCT/NGSP-HbA1c 13,7\% (IFCC-HbA1c126,23mmol/ml) - референтна вредност: < 7\%; општи преглед урина: без кетона, умерена гликозурија; серолошке анализе на антигене вируса: COXACIAE вирус B - IgG антитела повишене вредности; имунолошке анализе: инсулин аутоантитела (IAA) - негативна, аутоантитела на декарбоксилазу глутаминске киселине (енгл. glutamic acid decarboxylase autoantibodies (GAD) - негативна, антитела на ћелије Лангерхансових острвца панкреса (енгл. islet cell antibodies (ICA) - негативна; анализа функције панкреаса: C - пептид у границама нормале; други хормони: Т3 - у границама нормале, T4 - у границама нормале, TSH - y границама нормале, Кортизол - у границама нормале.

Након тродневне инсулинске терапије у хоспиталним условима пацијент постаје агликозуричан. Отпушта се са дијагнозом Diabetes mellitus тип 1, у добром општем стању са терапијом: ујутру - инсулин MIXTARD10-18 IJ, увече - инсулин MIXTARD 4 IJ; обавезан планирани режим исхране; упутство да се постепено смањује доза инсулина до потпуног искључења; појачана физичка активност и редукција тежине до 10 кг.

Пацијенту је састављен индивидуални јеловник, усклађен са препорукама Дијабетског савеза Србије (Diabetes Association of Serbia (DAS) (Табела 1):

Табела 1. Пример једнодневног јеловника.

\begin{tabular}{|c|c|c|c|c|c|c|}
\hline $\begin{array}{l}\text { Тип } \\
\text { оброка }\end{array}$ & $\begin{array}{l}\text { Врста } \\
\text { намирнице } \\
\text { количина }(\mathrm{g})\end{array}$ & $\begin{array}{l}\text { Енергетска } \\
\text { вредност } \\
\text { намирнице } \\
(\mathrm{kcal})\end{array}$ & $\begin{array}{l}\text { Протеини } \\
\text { (g) }\end{array}$ & $\begin{array}{l}\text { Угљени } \\
\text { хидрати } \\
\text { (g) }\end{array}$ & $\begin{array}{l}\text { Масти } \\
(\mathrm{g})\end{array}$ & $\begin{array}{l}\text { Холестерол } \\
(\mathrm{mg})\end{array}$ \\
\hline \multirow[t]{4}{*}{ Доручак } & $\begin{array}{l}\text { печеница } \\
(100 \mathrm{~g})\end{array}$ & 239 & 19 & 0 & 17 & 70 \\
\hline & $\begin{array}{l}\text { интегрални } \\
\text { хлеб }(50 \mathrm{~g}) \\
\end{array}$ & 125 & 4 & 25 & 0 & 0 \\
\hline & $\begin{array}{l}\text { јогурт } 0,5 \% \\
\text { млечних масти } \\
(200 \mathrm{ml})\end{array}$ & 68 & 6,4 & 8,6 & 1 & 0 \\
\hline & $\begin{array}{l}\text { немасни сир } \\
(50 \mathrm{~g})\end{array}$ & 85 & 6 & 1 & 6 & 16 \\
\hline Укупно & & 517 & 35,4 & 34,6 & 25 & 86 \\
\hline \multirow[t]{2}{*}{ Ужина } & брескве (200 g) & 92 & 2 & 12 & 0 & 0 \\
\hline & $\begin{array}{l}\text { воћни сок } 100 \% \\
(200 \mathrm{ml})\end{array}$ & 94 & 0 & 12 & 0 & 0 \\
\hline Укупно & & 186 & 2 & 24 & $\mathbf{0}$ & $\mathbf{0}$ \\
\hline
\end{tabular}




\begin{tabular}{|c|c|c|c|c|c|c|}
\hline \multirow[t]{4}{*}{ Ручак } & риба (200 g) & 220 & 36 & 0 & 14 & 70 \\
\hline & хлеб (50 g) & 125 & 14 & 25 & 0 & 0 \\
\hline & салате (200 g) & 20 & 4 & 2 & 0 & 0 \\
\hline & грашак $(200 \mathrm{~g})$ & 174 & 2 & 13 & 2 & 0 \\
\hline Укупно & & 539 & 56 & 40 & 16 & 70 \\
\hline Ужина & $\begin{array}{l}\text { банана } \\
(1 \text { комад) }\end{array}$ & 150 & 1 & 23 & 0 & 0 \\
\hline Укупно & & 150 & 1 & 23 & $\mathbf{0}$ & $\mathbf{0}$ \\
\hline \multirow[t]{3}{*}{ Вечера } & $\begin{array}{l}\text { печена } \\
\text { пилетина } \\
(200 \mathrm{~g}) \\
\end{array}$ & 214 & 22 & 0 & 4 & 70 \\
\hline & $\begin{array}{l}0,5 \% \mathrm{~mm} \text { јогурт } \\
(200 \mathrm{ml})\end{array}$ & 68 & 6,4 & 8,6 & 1 & 0 \\
\hline & салате $(200 \mathrm{~g})$ & 40 & 2 & 6 & 0 & 0 \\
\hline Укупно & & 322 & 30,4 & 14,6 & 5 & 70 \\
\hline $\begin{array}{l}\text { Укупан } \\
\text { дневни } \\
\text { унос }\end{array}$ & & 1714 & 140 & 135 & 46 & 216 \\
\hline
\end{tabular}

Препоручен дневни енергетски унос од 1.800-2.000 kcal, подељен у 5 оброка: доручак $550 \mathrm{kcal}$; ручак $650 \mathrm{kcal}$; вечера $400 \mathrm{kcal}$; и две ужине од по $200 \mathrm{kcal}$. Препоручени повољан дневни унос угљених хидрата је био испод $200 \mathrm{~g}$; масти испод $100 \mathrm{~g}$; и протеина $0,85 \mathrm{~g}$ по kg телесне масе. Режим планиране исхране је усклађен и са пирамидом правилне исхране по препоруци Америчког удружења за борбу против дијабетеса (енгл. American Diabetes Association, ADA), а са циљем да се у адекватним количинама обезбеди правилан унос потребних намирница.

По овој препоруци основни и највећи унос чине махунарке, интегралне житарице и њихови производи, затим воће и поврће у већим количинама (чиме се обезбеђује повољан унос биљних влакана), рационалан унос посних меса, рибе, јаја (главни извори градивних протеина), одмашћених млечних производа, орашасто воће (висок садржај минерала), као и минимални унос слаткиша, масноћа и грицкалица.

При коришћењу намирница, препоручен је и најоптималнији темпо уноса: житарице и махунарке, као и свеже воће и поврће и млечни производи свакодневно, месо, риба, јаја неколико пута недељно, слаткиши и грицкалице неколико пута месечно.

У препорукама је прецизиран и здрав начин припреме хране: барена, печена са минималном масноћом или у сопственој масноћи (Табела 1).

У сарадњи сапацијентом и његовом породицом, уз изузетну самоконтролу у првом месецу ремисионог периода, применом планираног режима исхране и појачаном физичком активношћу, постигнуто је следеће: смањена је телесна тежина за 4 кg; искључена је инсулинска терапија; лабораторијски параметри су у границама нормале; пацијент укључен у нормалне дневне и радне активности; консултативни преглед ендокринолога указује на повољну гликорегулацију, стабилност здравственог стања и предлаже планирану исхрану као једини терапијски третман у даљем лечењу.

У сарадњи са ординирајућим лекаром, пацијент је упознат са природом своје болести, како и када да контролише гликемују, као и да најмање два пута недељно израђује гликемијске профиле; упознат је са симптомима хипо и хипергликемије, ургентности терапије и самопомоћи у таквим стањима. 
Уз самодисциплину овако добро едукованог пацијента, планираним режимом исхране постигнута је успешна четворогодишња ремисија: са стабилном гликорегулацијом, стабилним лабораторијским параметрима
(Табела 2). Поред тога, очувана је панкреасна резерва, спречен је развој компликација, а пацијенту је омогућено прогресивно функционисање.

табела 2. Приказ лабораторијских параметара за период четворогодишье ремисије.

\begin{tabular}{|c|c|c|c|c|c|c|c|c|c|c|c|c|c|c|c|}
\hline & \multicolumn{3}{|c|}{ 2007. година } & \multicolumn{3}{|c|}{ 2008. година } & \multicolumn{3}{|c|}{ 2009. година } & \multicolumn{3}{|c|}{ 2010. година } & \multicolumn{3}{|c|}{ 2011. година } \\
\hline & 4.7. & 7.3 . & 3.12. & 10.3 . & 19.6. & 3.10 . & 16.1. & 27.5 . & 11.12. & 25.2 . & 5.7. & 11.11. & 4.3. & 28.4 . & 16.11 . \\
\hline $\begin{array}{l}\mathrm{HbAlc} \\
(\%)\end{array}$ & 7,7 & 6,7 & 5,4 & 5,8 & 6,1 & 5,6 & 5,4 & 5,9 & 6,1 & 6,8 & 5,0 & 5,8 & 7,2 & 6,4 & 6,1 \\
\hline $\begin{array}{l}\text { C-peptid I } \\
(\mathrm{ng} / \mathrm{ml})\end{array}$ & 1,1 & 1,5 & 0,88 & 1,2 & 1,1 & 0,9 & 1,1 & 2,9 & 1,6 & 1,3 & 0,82 & 1,2 & 0,98 & 1,1 & 0,81 \\
\hline $\begin{array}{l}\text { C-peptid } \\
\text { II (ng/ml) }\end{array}$ & 1,9 & 1 & 1,9 & 1 & 1,9 & 1,7 & 2,6 & 1 & 1 & 2,2 & 1,5 & 2,6 & 3,8 & 1,9 & 1 \\
\hline $\begin{array}{l}\text { holesterol } \\
(\mathrm{mmol} / \mathrm{l})\end{array}$ & 4,2 & 6,6 & 4,4 & 4,9 & 4,6 & 5,3 & 4,9 & 4,9 & 4,8 & 3,8 & 3,9 & 3,6 & 4,3 & 4,1 & 4,0 \\
\hline $\begin{array}{l}\text { trigliceridi } \\
(\mathrm{mmol} / \mathrm{l})\end{array}$ & 1,7 & 1,2 & 1,5 & 1,4 & 1,1 & 1,4 & 1,2 & 0,9 & 1,6 & 0,7 & 1,2 & 1,1 & 1,5 & 1,2 & 0,81 \\
\hline $\begin{array}{l}\text { urea } \\
(\mathrm{mmol} / \mathrm{l})\end{array}$ & 4,9 & 6,4 & 7,8 & 5,5 & 2,3 & 6,1 & 5,3 & 4,3 & 3,9 & 3,8 & 4,2 & 4,7 & 2,7 & 3,8 & 3,6 \\
\hline $\begin{array}{l}\text { kreatinin } \\
(\mathrm{mmol} / \mathrm{l})\end{array}$ & 42 & 70,2 & 94,6 & 51,4 & 70,8 & 44,1 & 65,1 & 71,2 & 70,8 & 78,5 & 60,8 & 92,8 & 61 & 70,1 & 67 \\
\hline $\mathrm{TV}(\mathrm{cm})$ & 159 & 163 & 165 & 165 & 167,5 & 168,2 & 168,9 & 169 & 169,8 & 170 & 170,9 & 171,2 & 171,5 & 172 & 172 \\
\hline $\mathrm{TM}(\mathrm{kg})$ & 56 & 57 & 57,6 & 63 & 66 & 64,6 & 65 & 63,2 & 64,3 & 63 & 64,5 & 69 & 62,7 & 64 & 69 \\
\hline
\end{tabular}

Априла 2011. године на предлог ендокринолога укључена је интензивирана инсулинска терапија са малим дозама инсулина са циљем предупређења дестабилизације болести услед промена у начину живота и варијацијама у начину исхране. Вишегодишња едукација о примени планиране исхране и позитивни резултати у контроли дијабетеса усмерили су пацијента да и даље користи планирани начин исхране. Уз редовну физичку активност и самоконтролу, пацијент са терапијом инсулином у наредном петогодишњем периоду одржава повољан ниво гликорегулације и оставља очувану панкреасну резерву, док лабораторијски параметри остају у границама референтних вредности.

\section{ДИСКУСИЈА}

У лечењу и контроли дијабетеса, а посебно код пацијената који су на интензивираној инсулинској терапији, поред примене фармакотерапије, морају се имплементирати и други начини лечења да би ce постигла повољна гликорегулација, дуга ремисија и стабилизација болести, посебно спречавање компликација примарне болести. Један од основних и најоптималнијих метода у контроли овог метаболичког синдрома је планирани режим исхране и промена у начину живота. ${ }^{(6)}$

Планирани енергетски унос за сваки оброк, као и адекватан целодневни калоријски унос је у нашем случају у првом месецу довео до ремисије и до редуковања телесне масе за 4 кg, што се у случају адолесцента у расту и развоју сматра реалним губитком.

Правилан распоред калоријског уноса за сваки оброк, као и коришћење у исхрани намирница које су сиромашне у сложеним шећерима, а богате биљним влакнима и пектином, постигнута је редукција доза потребног инсулина до његовог потпуног искључења из терапије. Контрола осећаја глади, спречавање неумерености у исхрани током главних оброка и, на тај начин, смањење потребе за инсулином постигнуто је поделом укупног калоријског уноса на пет оброка. ${ }^{(7)}$ 
Према студијама истраживача ADA установљено је да је за сагоревање $12 \mathrm{~g}$ угљених хидрата потребно 1-2 IJ инсулина. Према томе, смањењем уноса угљених хидрата смањује се и потреба за инсулином, а тиме се смањује и оптерећење панкреаса, као и дозе потребне фармакотерапије. У конкретном случају применом у исхрани намирница сиромашних у угљеним хидратима и сложеним шећерима дато је довољно времена инсулину да искористи унету глукозу. Примењивањем у исхрани намирница богатих биљним влакнима и пектином (воће и поврће, интегралне житарице и њихови производи, махунарке) са успореним транзитом у организму успоравана је реапсорпција глукозе. Код пацијента, адолесцента у расту и развоју, у планирању оброка је испоштована и потреба за другим нутритијентима: беланчевинама, мастима, минералима и витаминима.

Такође, у планирању исхране била је битна примена намирница у свежем стању, намирница са заслађивачима (кекс, чоколада, напици), као и намирница богатих омега киселинама и минералима (риба, језграсто воће). ${ }^{(6)}$

У конкретном случају на резултате гликорегулације и успешну ремисију утицао је и сам начин припреме хране, барена и печена са мало додате масноће или у сопственој. На постигнуте резултате у приказаном случају утицало је и планирање оброка према пирамиди исхране по препоруци ADA. ${ }^{(6)}$

Планирана исхрана је прво као део терапије, а затим и као једина терапија, довела пацијента до ремисије у првом месецу после установљења обољења. Телесна маса је редукована, постигнута је повољна гликорегулација, стабилан липидни статус, очувана панкреасна резерва. Такође, планираном исхраном, као једином терапијом у даљем току лечења, постигнута је успешна четворогодишња ремисија са стабилном гликорегулацијом. У прилогтоме говоре вредности НbA1c које су редовно контролисане (три пута годишње) и кретале су се у опсегу од 5 до 7,2\% (референтни опсег: код дијабетеса до 9\%). Очувана је функција панкреаса, чему у прилог томе говоре вредности С-пептида, који је контролисан у адекватним временским размацима, а вредности су се кретале у стандардном опсегу за С-пептид I од 0,8 до 2,9 $\mathrm{ng} / \mathrm{ml}$ и за С-пептид II од 0,8 до $3,8 \mathrm{ng} / \mathrm{ml}$ (Табела 2). Липидни статус био је у референтним вредностима, као и вредности урее и креатинина.

Интензивирана инсулинска терапија, заснована на малим дозама, уз планирани режим исхране, у даљем току болести одржала је стабилном гликорегулацију и спречила прогресију болести, као и појаву компликација. ${ }^{(7)}$

Планирана исхрана као део терапије Diabetes mellitus-a типа 1 или као једина терапија може показати овакве резултате само код добро едукованог пацијента који је упознат са природом болести и начинима успешног лечења, и који препознаје симптоме хипо и хипергликемије и упознат је са начинима самопомоћи у тим стањима.

\section{ЗАКЉУЧАК}

На основу свега наведеног закључујемо да се применом нутритивне терапије у лечењу дијабетеса типа 1 са очуваном панкреасном резервом, постиже смањење дозе потребне медикаментозне терапије у корелацији са гликемијским профилима, смањује оптерећењепанкреаса, ублажавајусимптоми хипо и хипергликемије. Постизањем задовољавајуће гликорегулације болест се добро контролише и, на тај начин, омогућава се дуга и успешна ремисија са стабилним лабораторијским параметрима.

Овакав терапијски метод у лечењу дијабета може бити веома ефикасан само код самодисциплинованог, добро едукованог пацијента који је успостављањем партнерског односа са лекаром, упознат са природом своје болести и најоптималнијим начинима лечења. 
Иако је Diabetes mellitus тип 1 хронично, прогресивно обољење, наведене методе лечења, као и самодисциплина пацијента, омогућавају да се ублаже симптоми бо- лести, спречи прогресија, развој компликација, а пацијент оспособи за здраво функционисање у породици и друштву.

\section{ЛИТЕРАТУРА}

1. Dabelea D, Mayer-Davis EJ, Saydah S, Imperatore G, Linder B, Divers J. et al. Prevalence of type 1 and type 2 diabetes among children and adolescents from 2001 to 2009. JAMA, 2014; 311(17): 1778-1786.

2. Phillips J, Phillips PJ. Children get type 2 diabetes too. Aust Fam Physician, 2009; 38(9): 699-703.

3. Edghill EL, Flanagan SE, Patch AM, Boustred C, Parrish A, Shields B, et al. Insulin mutation screening in 1,044 patients with diabetes: mutations in the INS gene are a common cause of neonatal diabetes but a rare cause of diabetes diagnosed in childhood or adulthood. Diabetes, 2008; 57(4): 1034-1042.

4. Amutha A, Mohan V. Diabetes complications in childhood and adolescent onset type 2 diabetes-a review. J Diabetes
Complications. 2016 Feb 9. pii: S10568727(16)00060-X. doi: 10.1016/j.jdiacomp. 2016.02.009. [Epub ahead of print]

5. Wheeler BJ, Lawrence J, Chae M, Paterson H, Gray AR, Healey D, Reith DM, Taylor BJ. Intuitive eating is associated with glycaemic control in adolescents with type I diabetes mellitus. Appetite, 2016; 96: $160-5$.

6. Chamberlain JJ, Rhinehart AS, Shaefer CF Jr, Neuman A. Diagnosis and Management of Diabetes: Synopsis of the 2016 American Diabetes Association Standards of Medical Care in Diabetes. Ann Intern Med. 2016 Mar 1. doi: 10.7326/M153016. [Epub ahead of print]

7. Copeland, Kenneth C., et al. Management of newly diagnosed type 2 diabetes mellitus (T2DM) in children and adolescents.. Pediatrics 2013; 131.2: 364-382.

8. ADA - American Diabetes Association.

Контакт: Др Весна Динов, Бунушевачка бб, 17500 Врање, тел: 0600417887 , e-mail:dinov92@ptt.rs 